\title{
Levels of Knowledge in the Area of Corporate Governance in the Czech Republic
}

\author{
Pavel Taraba, Romana Bartošíková and Jana Biliková \\ Tomas Bata University in Zlín, Faculty of Logistics and Crisis management, Zlín, Czech Republic \\ Correspondence should be addressed to: Pavel Taraba; taraba@flkr.utb.cz
}

Received date: 6 March 2015; Accepted date: 3 July 2015; Published date: 23 February 2016

Academic Editor: Maria Viorica Bedrule-Grigoruta

Copyright @ 2016. Pavel Taraba, Romana Bartošíková and Jana Biliková. Distributed under Creative Commons CC-BY 4.0

\begin{abstract}
The paper introduces the basic concept of Corporate Governance with emphasis on the education of members of corporate governance bodies. The introduction defines three levels of knowledge, management board and supervisory board members in the corporate governance. The main objective of the research was to compare the level of application of knowledge of Corporate Governance of members of Corporate Governance bodies of multinational organizations and Czech organizations doing businesses in the Czech Republic. The method of questionnaire survey was used for data collection as one of the methods of quantitative research. The results were statistically evaluated in the context of descriptive statistics. The chisquare was used to verify the hypotheses. Based on the results of the research, the critical areas have been identified and the recommendations to organizations operating in the Czech Republic have also been formulated. Problem areas, which should be taken into consideration to gain competitive advantage of the organization in the Czech Republic, are the selecting process of members of corporate government bodies and their knowledge of corporate governance. Applying the knowledge of multinational organizations in corporate governance area is one of the ways to increase the level of competitiveness of organizations doing business in the Czech Republic.
\end{abstract}

Keywords: Corporate Governance, Corporate Governance bodies, Knowledge, the Czech Republic

\section{Introduction}

The level of knowledge in the area of Corporate Governance not under the Czech or foreign literature is clearly defined. Jirasek (2001) and Klírová (2001) reported that members of Corporate Governance bodies

Cite this Article as: Pavel Taraba, Romana Bartošíková and Jana Biliková (2016), “ Levels of Knowledge in the Area of Corporate Governance in the Czech Republic", Journal of Eastern Europe Research in Business \& Economics, Vol. 2016 (2016), Article ID 445900, DOI: 10.5171/2016.445900 
should have at least basic knowledge in management.

Authors define three levels of education in the corporate governance. The basic level of knowledge in the area of Corporate Governance represents knowledge on current trends in management, the methodology of systemic thinking on the management unit (object), the management functions and the information used for the management. Within a higher level of knowledge in the area of Corporate Governance, knowledge of strategic management and knowledge of the Principles of Corporate Governance are defined. Advanced level of knowledge in the area of Corporate Governance is represented by certificates - Corporate Governance Director or Corporate Governance - Company Secretary.

\section{Literature review}

We mention three levels of knowledge in the corporate governance (basic level, higher level and advanced level).

\section{Basic level of knowledge in the area of Corporate Governance}

The basic level of knowledge management is based on the concept of holistic management. At this level, we assumed knowledge of members of the Corporate Governance bodies:

- On current trends in management,

- Methodology of systematic thinking,

- The management unit (object),

- The management functions,

- The information used by the management. (Porvazník and Ladová, 2010)

Market globalization brings new challenges and new opportunities, but on the other hand, conflicts and threats. Changing dynamics of the external environment brings out unexpected opportunities and risks and threats. It all entails new challenges and new requirements to address them. It is desirable that members of the Corporate Governance bodies in the Czech Republic have at least a basic knowledge of current trends and management to be able to apply them in the development of the organization.

To the forefront of managerial theory and practice, there are getting various managerial trends. Based on the analysis of available information sources, we identified the rehabilitation of the following modern trends related to the development of organizations, not only in the Czech Republic. TQM - Total Quality Management, MBO - Management by Objectives, TQEM - Total Quality Environmental Management, BSC - Balanced Scorecard, CRM - Customer Relationship Management, CPM - Corporate Performance Management, Six Sigma, Reengineering, IDS Scheer, CSR - Corporate Social Responsibility, Outsourcing, Knowledge Management, Benchmarking, Core business, Kaizen, Shareholder value, Stakeholder value. (Porvazník and Ladová, 2010)

Members of the Corporate Governance bodies doing business in the territory of the Czech Republic should be able to apply particular managerial trends into practice and demonstrate their use in the development of their organization. In the Czech Republic, management approaches to a sufficient extent (TQM, Outsourcing and CRM) are used, but other management approaches have not been used at all or only to a limited extent (Stakeholder value, Reengineering). The main reason may be their ignorance or opposition of the Corporate Governance bodies to introduce new methods and management techniques into practice.

System approach is mainly applied in solving complex problems that interfere with a number of different fields of human knowledge (so-called interdisciplinary problems). (Lacko, 2011) 
In the next section, we focused mainly on the organization as management objects. Members of the Corporate Governance bodies have knowledge in particular that:

- What parts - units (divisions, departments, sections) are at the core of every organization,

- How the individual parts - bodies involved in fulfilling the mission of the organization,

- What factors (factors, characteristics, indicators) of the external and internal environment of the organization affect its performance, sustainable development in the fulfillment of its mission,

- Activities through which organizations deal with environmental influences, as in fulfilling their mission in organizations exist and how they affect the performance of organizations. (Porvazník and Ladová, 2010)

Then, traditional management functions (despite the diversity of definitions) are reported in the literature following activities: planning, organizing, leading, control, monitoring and coordination. Having known these features, we included also the basic knowledge of members of the Corporate Governance bodies in the Czech Republic.

- Information work is considered to be one of the basic competences of management entities. Information generated by data analysis emerges in three basic categories:

- Information about the role of objects,

- Information for the implementation of the functions of management (planning, organizing, leading, control, monitoring and coordination),

- Information on the relationships between object,

- The current IT environment is characterized by an explosion of resources records and dissemination of information and it is not easy in a variety of information sources to navigate. (Dubovec, 2011)

\section{Higher level of knowledge in the area of Corporate Governance}

When characterizing a higher level of knowledge that the members of management boards and members of supervisory boards should have and apply in Corporate Governance, we assumed that they have a basic knowledge of management as defined in the previous section.

These basic knowledge we have expanded the knowledge of strategic management, where we were based primarily on the concept of Slavik (2009) and knowledge of Corporate Governance based on the Principles of Corporate Governance (OECD, 2004) and the Corporate Governance Code (2004).

At this level, are expected to be members of Corporate Governance bodies:

- The vision, mission and objectives of the organization,

- The strategy of the organization at the corporate and business level,

- The Principles of Corporate Governance.

In the next section, we define the basic concepts of strategic management.

The vision outlines the most general concepts and conceptual vision of the future direction and status of the company. It answers the questions:

- Where do we want to get or where shall we get?

- What should we do or shall we do?

- Who should we become or want to become?

Pavel Taraba, Romana Bartošíková and Jana Biliková (2016), Journal of Eastern Europe Research in Business \& Economics, DOI: 10.5171/2016.445900 
Formulating and implementing effective mission is to meet the following three tasks:

- Understand and define if the business company is actually present,

- Decide when to change the mission, and thus adjust the strategic direction of the company.

- Inform the staff undertaking the mission about using methods that are understandable, interesting and challenging.

Clear objectives represent the basis for monitoring progress towards implementation of the mission. Targets for the management and other management levels are commitments to achieve particular results at a particular time. (Slávik, 2009)

It is imperative that members of the Corporate Governance bodies have the necessary knowledge in the field of strategic management. Work on the strategy is a matter of authority, company owners (shareholders), senior management and professional body with executive authority, strategic thinking remains top management. Although the body of shareholders deals with the challenges of a strategic nature, it rarely plays a leading role in formulating strategy. The body of shareholders evaluates, selects and approves the strategic options presented, drawn up by senior management, and bears full responsibility for them.

The body of shareholders may be involved in the management of joint-stock company in varying degrees:

- It evaluates - is passive, examines, evaluates and approves proposals for executives.

- It encourages - approves and submits proposals particularly in the area of strategic development.

- It determines - involves in varying degrees to create variants for strategic decisions, clearly defines the space for themselves and for the senior managers (management). (Slávik, 2009)

Corporate strategy is formulated at the highest level of management in the organization. Major strategic decisions usually examine the Corporate Governance bodies (Management Board, Supervisory Board) in organizations. This strategy responds to the question of how to organize a set of businesses in which it operates, in order to achieve the objectives for the company as a whole part. Its main task is to manage the portfolio (file or set) business.

It addresses the following subtasks:

- Allocation of capital investment in existing business,

- Reduction of investment or cancellation of unprofitable or loss-making business,

- Expansion of the portfolio of new business and building new positions in attractive industries,

- Strengthening the competitive position and profitability of existing business,

- Creating competitive advantage to the company level through related business,

- Deciding on the type and extent of diversification. (Slávik, 2009)

Responsibility for formulating business strategy carries the head of a business unit, with major strategic decisions scoring by the approval of the senior management level. This strategy responds to the question of how to develop and promote long-term competitive position in the market, and so fulfill the objectives of the business unit. It is a strategy of the business unit, in which the sector operates relatively independently of management.

Addresses the following subtasks:

- Formulating responses to changes in the sector in the economy as a whole, in 
government policy and other important areas,

- The formulation of competitive measures and market-based approaches that will lead to sustainable competitive advantage,

- Alignment of strategic initiatives' functional departments,

- Specific problems that are typical only for the business unit. (Slávik, 2009)

There is a relationship between Corporate Governance and achievement of strategic management and marketing goals. Linking Corporate Governance and Strategic Marketing is often mentioned by different ways. Moiz and Abidi (2011) mentioned the fact that the organizations we talk about are not simply practicing marketing without understanding its full potential; rather they are implementing marketing techniques which are strategic in nature. These organizations have aligned their marketing goals with the organization's business goals, take their competition into account in the pursuit of their goals and objectives, and have both a futuristic and realistic approach towards their vision.

According to Kramoliš (2012), it must be also mentioned that most of respondents strongly disagree with using any unethical marketing technique according to this segment of respondents, the use of Embedded marketing is unethical in principle.

At this level, members of Corporate Governance bodies should have knowledge in the area of Corporate Governance. The main findings contained in the Corporate Governance Code (2004) based on the Principles of Corporate Governance (OECD, 2004) consider:

- Ensuring the effective Corporate Governance,
- Ensuring the protection of shareholders' rights,

- Ensuring the equal access to shareholders,

- Strengthening the rights of shareholders,

- Ensuring accountability of the Management Board,

- Ensuring transparency of information concerning the company.

\section{An advanced level of knowledge in the area of Corporate Governance}

With the growing awareness of the performance of duties of its members and the legal and moral responsibilities associated with it, there is an increasing interest in the efficient development program to prepare candidates as well as current members of the Management boards and Supervisory boards to exercise their functions. (CG Partners, 2008)

Just respond to this challenge of National Certification Program Study of Corporate Governance, which we consider a successful completion of the higher level of knowledge in the area of Corporate Governance. Within this national certification program of study, Corporate Governance certificates are issued:

- Corporate Governance - Director,

- Corporate Governance - Company Secretary. (CG Partners, 2011b)

Kavalír emphasizes the added value of the modular certification training for practice, he also argues that the education system is at the top European level organizations and valued members of the Corporate Governance bodies of the countries of the European Union, those systems are only beginning to build. A similar system has only Great Britain (Institute of Directors, IoD Chartered Director program). (Kavalíŕ, 2005)

Pavel Taraba, Romana Bartošíková and Jana Biliková (2016), Journal of Eastern Europe Research in Business \& Economics, DOI: 10.5171/2016.445900 
The basic pillars of National Certification Program Corporate Governance - Director program can be characterized as follows:

- Selection program for managers in the difficult position of member of the Management Board and Supervisory Board,

- Focus on key issues of Management Board and the Supervisory Board in strengthening the competitiveness of organizations,

- Examples and experience from top multinational and Czech companies (best practices),

- Practical support for experienced professionals - emphasis on methods useful in practice, the maximum time pertinence and efficiency,

- Continuous transfer of new knowledge and methods in the work of directors and Supervisory boards of the participating organizations,

- The possibility of engaging in an exclusive network of professional independent members of the administrative,

- Space for individual questions. (CG Partners, 2011b)

This program is accredited by the Ministry of Education, Youth and Sports as retraining, its focus and structure significantly extends the classical management and MBA education. (CG Partners, 2008)

Another certification program is Corporate Governance - Company Secretary based on the experience and requirements of the participants of the training program Corporate Governance - Director and is a measure of the importance of the labor secretary of a company. It is also accredited by the Ministry of Education, Youth and Sports. (CG Partners, 2011a)

This program:
- Provides a comprehensive training to cope with the administration of administrative processes all aspects affecting the development of best practices of Corporate Governance at the national and international context,

- Formulates key competences of a Company Secretary as a long-term competitive advantage,

- Is intended for all who practice successfully applied their managerial skills and perform, or to serve as Company Secretary (Corporate Secretary) or the Secretary of the Corporate Governance bodies. (CG Partners, 2011a)

By Klírová (2001) and Kavalír (2005), for the future strength of organizations in the Czech Republic, we can consider the growing interest in education in the area of Corporate Governance and increasing efforts to the excellence of administration of administrative processes of managers, Corporate Governance bodies, willingness to adopt new knowledge and input of some Czech business companies in global capital markets, which are fully able to meet the demanding requirements of regulators of these markets.

\section{Research design and methodology}

The following chapter is focused on clarifying the procedures and methods that were used in the processing of the present article. In its treatment, it was necessary to use a whole variety of methods and techniques, known as logical methods and the methods used in the context of quantitative research.

Abstraction belonged to the methods used in the paper - ideational process which separates only the essential characteristics of a particular object, particularity - ideational process, when you search for a particular occurrence of a specific object analysis - the process of allocating of the whole part, mainly used in the analytical part of the paper in formulating the research problem, synthesis - the process from parts to the 
whole (linking knowledge), used for example in formulating conclusions.

In the context of evaluating questionnaire was used interval measurement and subsequently they were mentioned in tables by value of scale average values (h), the percentage expressing scale values (p) mode - the most frequently occurring value of the reference symbol $h(\mathrm{Mo})$, median - the middle value of the reference character (Me), standard deviation scale value (s) and the coefficient of variation (V).

With the help of the chi - square test, we verified figures, which were obtained by measuring the reality and they differ from the theoretical proliferation, which corresponds to a given zero hypothesis. Chi square test begins by formulating a zero and alternative hypothesis. Generally speaking, the null hypothesis (denoted $\mathrm{H}_{0}$ ) is the assumption that there is no relationship between phenomena like continuity and contrast. Alternative hypothesis (denoted $\mathrm{H}_{1}$ or $\mathrm{H}_{\mathrm{A}}$ ) is a contrary assumption that there is a relationship between the observed phenomena like continuity and contrast.

- In the first step, this hypothesis was generated: Members of the Corporate Governance bodies in multinational organizations apply knowledge of Corporate Governance to a greater extent than the members of the Corporate Governance bodies in the Czech organizations.

- The next stage represents a critical review of the literature. By using different and relevant data, the sources are conducted and elaborated in a theoretical background that supports the arguments and statements, demonstrates the familiarity with a field of research, namely the articles in refereed academic journals, books, newspapers, annual reports and the searching of the available and relevant home pages via the Internet belong among the variety of secondary data.
- The third step includes an illustration of authors ' reasoning and concerning the analysis, using a questionnaire survey.

For the purpose of this text, the data used were primarily from the quantitative phase. The questionnaire was constructed and based on the study of primary and secondary sources listed above. This pilot survey was conducted in the selected branch offices several stock companies with a foreign participation in the Czech Republic through a questionnaire. Based on the feedback, which we was received from respondents who participated in the pilot research, questionnaire was modified and subsequently discussed with experts using Delf's methods. Within the team, we provide sufficient reliability research for the implemented purpose of this article. The questionnaire was based on the following types of questions:

- Two closed multiple - choice questions Regarding the graduated study program in the education of CG area by members of the Corporate Governance Bodies,

- Eight ranking scale questions concerning the knowledge of the general management, strategic management of knowledge, knowledge of CG principles used in the organization and the management Implicated trends in selected Organizations.

Data collection was used by questionnaire. The questionnaire was sent by classical or by e-mail. Data collection was conducted from April 2012 to April 2013.

The sample consisted of 300 respondents. These respondents were selected on the basis of a deliberate choice. The team examined did not decide the element of chance, but the judgment of the researcher. Control characters when creating quota sampling were memberships in the Management board or Supervisory board. The final number of processed questionnaires was 103 , i.e. the rate was $34.33 \%$.

Pavel Taraba, Romana Bartošíková and Jana Biliková (2016), Journal of Eastern Europe Research in Business \& Economics, DOI: 10.5171/2016.445900 
Questionnaire as a method of quantitative research is appropriate to use the terms that the author of the questionnaire has secured them a sufficient return. Under this condition over the applicable method, the main benefits are:

- Low cost of data collection,

- The possibility of recouping a large sample of respondents,

- Relatively, low time-consuming.

The survey questionnaire was assured, return for help colleagues and personal contacts gained during the period of cooperation with practices that contributed to the high rate of return questionnaires.

The method used, has a certain limit. The success of the questionnaire survey was necessary to ensure that respondents were only members of the Corporate Governance bodies. This is related to a lower number of evaluated questionnaires, as regards the specific issues and potential research respondents, they are considerable workload and their attitude to the questionnaire survey was largely dismissive.

\section{Results}

Based on the analysis of available domestic and foreign information sources, we identified the rehabilitation of this paper in three levels of knowledge in the area of Corporate Governance: basic level, higher level and advanced level.

\section{Basic level of knowledge in the area of Corporate Governance}

The evaluation of the questionnaire, we found that for the best knowledge at basic level respondents considered the management unit (object) (adequate scale value 2.31 ) and the information used by the management (adequate scale value 2.36).

The worst fact was knowledge of methodology of systematic thinking. Up to $21.35 \%$ of respondents completely or mostly disagreed with the statement, "members of corporate governance body having knowledge of the methodology of systematic thinking."

Table 1: Basic level of knowledge in the area of Corporate Governance

\begin{tabular}{|l|l|l|l|l|l|l|l|l|l|l|l|}
\hline & \multicolumn{3}{|l|}{ Abs. frequency (n) } & h & p (\%) & Mo & Me & s & V (\%) \\
\cline { 2 - 9 } & h1 & h2 & h3 & h4 & h5 & & & (h) & (h) & & \\
\hline $\begin{array}{l}\text { Current trends } \\
\text { in } \\
\text { management }\end{array}$ & 25 & 29 & 19 & 27 & 3 & 2,55 & 38,83 & 2 & 2 & 1,20 & 47,09 \\
\hline $\begin{array}{l}\text { The } \\
\text { management } \\
\text { unit (object), }\end{array}$ & 29 & 37 & 18 & 14 & 5 & 2,31 & 32,77 & 2 & 2 & 1,16 & 50,35 \\
\hline $\begin{array}{l}\text { The } \\
\text { management } \\
\text { functions }\end{array}$ & 16 & 40 & 29 & 13 & 5 & 2,52 & 38,11 & 2 & 2 & 1,06 & 41,82 \\
\hline $\begin{array}{l}\text { The } \\
\text { information } \\
\text { used by the } \\
\text { management }\end{array}$ & 28 & 29 & 32 & 9 & 5 & 2,36 & 33,98 & 3 & 2 & 1,12 & 47,43 \\
\hline $\begin{array}{l}\text { Methodology of } \\
\text { systematic } \\
\text { thinking }\end{array}$ & 19 & 33 & 29 & 17 & 5 & 2,57 & 39,32 & 2 & 2 & 1,12 & 43,41 \\
\hline
\end{tabular}

Pavel Taraba, Romana Bartošíková and Jana Biliková (2016), Journal of Eastern Europe Research in Business \& Economics, DOI: 10.5171/2016.445900 
Higher level of knowledge in the area of Corporate Governance

The respondents reached the top of knowledge into a higher level in vision, mission and objectives of the organization. It is positive that 49 respondents of the participating research are fully toyed with the statement that the members of the Corporate Governance body having knowledge about the vision, mission and objectives of the organization. The mean scale value of the criterion was preferably in the context of all the evaluated criteria, occurring within the quantitative research (2.04).

Table 2: Higher level of knowledge in the area of Corporate Governance

\begin{tabular}{|c|c|c|c|c|c|c|c|c|c|c|c|}
\hline & $\overline{\text { Abs }}$ & frec & $\overline{\text { ienc }}$ & & & $\bar{h}$ & p (\%) & Mo & Me & $\mathbf{s}$ & $\overline{V(\%)}$ \\
\hline & h1 & h2 & h3 & h4 & h5 & & & (h) & (h) & & \\
\hline $\begin{array}{l}\text { The vision, } \\
\text { mission and } \\
\text { objectives of } \\
\text { the } \\
\text { organization }\end{array}$ & 49 & 28 & 8 & 9 & 9 & 2,04 & 25,97 & 1 & 2 & 1,31 & 64,03 \\
\hline $\begin{array}{l}\text { The strategy } \\
\text { of the } \\
\text { organization } \\
\text { at the } \\
\text { corporate and } \\
\text { business level }\end{array}$ & 41 & 26 & 11 & 15 & 10 & 2,29 & 32,28 & 1 & 2 & 1,38 & 60,08 \\
\hline $\begin{array}{l}\text { The } \\
\text { Principles of } \\
\text { Corporate } \\
\text { Governance }\end{array}$ & 25 & 39 & 21 & 12 & 6 & 2,37 & 34,22 & 2 & 2 & 1,15 & 48,38 \\
\hline
\end{tabular}

It stresses that only $9.71 \%$ of research participants stated that members of the Corporate Governance bodies have no knowledge of the strategy of the organization at the corporate and business level, which may mean for the functioning of organizations other significant problems. In evaluating the criteria for the application of the Principles of Corporate Governance, 64 respondents (61.54\%) indicated that they fully or partially agree that the members of the Corporate Governance bodies have knowledge bring into the Code of Corporate Governance (2004).

\section{An advanced level of knowledge in the area of Corporate Governance}

As we have shown in the following table, only $2.91 \%$ of the members of the Corporate Governance body have successfully completed a national certification program of Corporate Governance - Director (three respondents). 
Table 3: An advanced level of knowledge in the area of Corporate Governance (Corporate Governance - Director)

\begin{tabular}{|l|l|l|}
\hline Corporate Governance - Director & $\mathbf{n}$ & $\mathbf{p ~ ( \% )}$ \\
\hline Yes & 3 & 2,91 \\
\hline No & 42 & 40,78 \\
\hline I do not know. I do not have any information. & 58 & 56,31 \\
\hline
\end{tabular}

From Table 4, it is seen that only $1.94 \%$ (two respondents) have successfully completed a national certification program Corporate Governance - Company Secretary and 56.31
$\%$ of respondents does not have information about these certification programs accredited by the Ministry of Education, Youth and Sports.

Table 4: An advanced level of knowledge in the area of Corporate Governance (Corporate Governance - Secretary)

\begin{tabular}{|l|l|l|}
\hline Corporate Governance - Secretary & $\mathbf{n}$ & $\mathbf{p ~ ( \% )}$ \\
\hline Yes & 2 & 1,94 \\
\hline No & 43 & 41,75 \\
\hline I do not know. I do not have any information. & 58 & 56,31 \\
\hline
\end{tabular}

As it can be seen from the above tables, the results which appear are almost identical. This is due to the fact that organizations aware of the existence of these certification programs are perceived by them collectively. For organizations whose members of the Corporate Governance bodies have not completed the certification program such as Corporate Governance - Director or lacked information about its existence, it is highly likely (a research confirmed it) that they do not even know about the second certification program.

The main objective of the research was to compare the level of application of knowledge of Corporate Governance for members of the Corporate Governance bodies of multinational organizations and Czech organizations doing business in the Czech Republic.

To the objectives we have established scientific hypothesis:
Members of the Corporate Governance bodies in multinational organizations apply knowledge of Corporate Governance to a greater extent than members of the Corporate Governance bodies in the Czech organisations.

It is necessary to define what we mean by a Czech organization and a multinational organization. Organizations with the majority of Czech ownership are considered to be Czech organizations and organizations with the majority of foreign ownership are considered to be multinational organizations (European and World). We emphasize that all organizations in which the research was conducted are businesses in the Czech Republic.

Organizations with Czech ownership accounted for $58.25 \%$ - share of organizations whose data were analysed in the framework of qualitative research. We also analysed data from the $16.50 \%$ of European organizations with the majority of 
owners (17 organizations) and $25.24 \%$

considered the world (26 organizations).

of organizations whose respondents

Table 5: Type of organization - ownership structure

\begin{tabular}{|l|l|l|}
\hline Type of organization & $\mathbf{n}$ & $\mathbf{p}(\mathbf{\%})$ \\
\hline Czech & 60 & 58.25 \\
\hline European & 17 & 16.50 \\
\hline World & 26 & 25.24 \\
\hline
\end{tabular}

Were also examined cumulatively European and world organizations like multinational

organizations. This breakdown describes the structure in table 6:

Table 6: Type of organization - Czech, Multinational

\begin{tabular}{|l|l|l|}
\hline Type of organization & $\mathbf{n}$ & $\mathbf{p ~ ( \% )}$ \\
\hline Czech & 60 & 58.25 \\
\hline Multinational & 43 & 41.75 \\
\hline & & \\
\hline
\end{tabular}

Based on the scientific hypothesis, we identified the hypothesis $\mathrm{H}_{0}$ and alternative hypothesis $\mathrm{H}_{1}$ :

$\mathrm{H}_{0}$ : The level of application of knowledge in the Corporate Governance area is dependent on the fact which member claimed it, whether a member of the Corporate Governance body of the Czech or a member of the multinational organization.
$\mathrm{H}_{1}$ : The level of application of knowledge in the Corporate Governance area depends on which member claimed it, whether a member of Corporate Governance body of the Czech organisation or a member of the multinational organization.

We use the $\chi 2$ - test.

Table 7: Application of knowledge in Corporate Governance area - Pivot table

\begin{tabular}{|l|l|l|l|l|l|}
\hline Type of organization & h1 & h2 & h3 & h4 & h5 \\
\hline Czech & 93 & 96 & 71 & 16 & 24 \\
\hline Multinational & 56 & 86 & 44 & 25 & 4 \\
\hline
\end{tabular}

Pavel Taraba, Romana Bartošíková and Jana Biliková (2016), Journal of Eastern Europe Research in Business \& Economics, DOI: 10.5171/2016.445900 
We have built a testing criterion - W:

$W=\left(\chi_{1-\alpha}^{2}((\right.$ columns -1$) \cdot($ lines -1$\left.)), \infty\right)=\left(\chi_{1-\alpha}^{2}((4) \cdot(1), \infty)\right)=(9,48, \infty)$

We have built a testing criterion:

$$
\chi^{2}=\sum_{i=1}^{k} \frac{\left(P_{i}-O_{i}\right)^{2}}{O_{i}}=\frac{\left(93-\frac{300 \cdot 149}{515}\right)^{2}}{\frac{300 \cdot 149}{515}}+\cdots+\frac{\left(25-\frac{215 \cdot 28}{515}\right)^{2}}{\frac{215 \cdot 28}{515}}=18,82
$$

We decided on the validity of hypotheses:

the questionnaires of 60 respondents from the Czech companies, we found the level of $\chi 2 \in \mathrm{W}$ reject $\mathrm{H}_{0}$ and accept $\mathrm{H}_{1}$ application of knowledge of Corporate Governance bodies means scale values $\mathrm{h}=$

Based on the conducted test, we can conclude: 2.27 and evaluating the questionnaires of 43 respondents from multinational companies, we found the level of application of knowledge of Corporate Governance bodies means scale values $h=2.23$. This means that the knowledge of Corporate Governance bodies in multinational organizations was applied at a higher rate.

bodies of the Czech or multinational organization claimed that. Having evaluated

Table 8: Application of knowledge in Corporate Governance area (Czech, multinational)

\begin{tabular}{|l|l|l|l|l|l|l|l|l|l|l|l|}
\hline & \multicolumn{4}{|l|}{ Abs. frequency (n) } & h & p (\%) & Mo & Me & s & V (\%) \\
\cline { 2 - 4 } & h1 & h2 & h3 & h4 & h5 & & & (h) & (h) & & \\
\hline $\begin{array}{l}\text { Czech } \\
\text { (n=300) }\end{array}$ & 93 & 96 & 71 & 16 & 24 & 2.27 & 31.83 & 2 & 2 & 1.19 & 52.23 \\
\hline $\begin{array}{l}\text { Multinational } \\
\text { (n=215) }\end{array}$ & 56 & 86 & 44 & 25 & 4 & 2.23 & 30.81 & 2 & 2 & 1.02 & 45.86 \\
\hline
\end{tabular}

NB. Each member of the Corporate Governance body answered 5 questions relating to the level of application of knowledge in Corporate Governance area, therefore, the total assessed number of responses in Czech organizations is 300 (60x5) and the total assessed responses in multinational organizations are $215(43 \times 5)$.

Based on these results, we can say that:

Members of the Corporate Governance bodies in multinational organizations apply knowledge in Corporate Governance area to a greater extent than members of the Corporate Governance bodies in the Czech organisations.

\section{Conclusion}

One of the main findings is that directors, executives, shareholders, supervisors, and in many cases, not enough auditors failed to meet its key role in Corporate Governance area. Corporate Governance bodies have not been able to exercise effective control, and management measures implemented comparative analysis or strategic orientations presented to them for approval. Shareholders exercised their obligations in full. Control authorities had clearly defined roles in managing organizations, and auditors often failed in their duties responsibly in managing organizations. 
In the paper, we examined the dependence of the level of application of knowledge of Corporate Governance bodies in the Czech and multinational organizations. We found that in multinational organizations doing business in the Czech Republic, knowledge of Corporate Governance bodies are applied to a greater extent than in the Czech organizations.

The majority of respondents of multinational organizations worked in the financial services sector. It should be noted that a stricter requesting of application of knowledge of Corporate Governance bodies can be observed (after the credit crunch) especially in financial institutions.

On the basis of the experience of multinational organizations, we have formulated recommendations for organizations operating in the Czech Republic. Organizations in the Czech Republic should pay more attention to particular knowledge level of members of their Corporate Governance bodies and systematic process of selecting these members to their supervisory boards and management board.

\section{The level of knowledge of members of Corporate Governance bodies}

Awareness of the emerging trends in the management is low. Many of the trends mentioned in the questionnaire are unfamiliar to our respondents and thus they should more apply the Corporate Governance in the organizations where they operate.

We also found out that members of the Corporate Governance bodies utilized their knowledge inefficiently in organizations in the Czech Republic. Written rules of formulated cooperation of administrative authority of the executives are rarely used. We can see a considerable room for improvement here.
On the basis of this knowledge, we have formulated the following recommendations:

- Emphasis on new trends in the management,

- Streamlining work with the information

New trends in the management, such as Core business, Reengineering, Shareholder value or Stakeholder value, are within the organizations in the Czech Republic only minimally used. One of the objectives under the conditions of application of knowledge in organisations in the Czech Republic should be just raising the awareness of managers, but also for owners of emerging trends in the management. We see the process in closer interconnection of cooperation between universities and practice forms of workshops and e-learning courses aimed at the specific needs of members of the Corporate Governance bodies. Also, we should pay more attention to law certification of members of the Corporate Governance bodies (Corporate Governance Director, Corporate Governance - Secretary).

The selection of members to the Corporate Governance bodies (Board of directors and Supervisory board) of organizations

According to Porvazník (2010), is a desirable development of members of the Corporate Governance body, which is a measurable benefit, a powerful element of emerging organizations, which rests on three basic pillars - competency, by:

- Pillar of professional knowledge,

- Pillar of practical skills,

- Pillar of social maturity.

The holistic competent member of the Corporate Governance body (Board of Directors, Supervisory Board) is one that is socially mature, has the necessary professional knowledge, practical skills 
needed and the human attitudes. Pillar of social maturity is didactic sequence spree as the first because of its importance to the practice. Pillar of social maturity is based on the characteristics of the subjects of personal management and forms their knowledge of the character's attributes and oxen, cognitive and creative characteristics, temperament and emotional qualities in a row but also somatic features (physiological and mental spiritual).

One of our long-term objectives is to acquaint members of the board of directors and Supervisory Board in the Czech Republic with the results obtained by analysing the available Czech, but especially the foreign information sources on the critical impact of social maturity on the success of the whole organization (e. g. Bata, Porvazník, Goleman, Owen and others). The selection of members with high social maturation is an important factor in the competitiveness of each organization in the current turbulent economic environment.

\section{Acknowledgements}

The authors would like to thank the dean of the Faculty of Logistics and Crisis Management for his support and the Tomas Bata University in Zlín for the opportunity to work on this paper.

\section{References}

1. CG Partners (2008) Určeno pro stávající členy i pro potenciální kandidáty na pozici členů představenstev a dozorčích rad. [online],

http://www.governance.cz/cs/cg-

vzdelavani-a-rozvoj/urceno-pro-stavajicicleny-i-pro-potencialni-kandidaty-na-poziciclenu-predtavenstev-a-dozorcich-

rad_s113x8669.html Available [05 Nov 2011].

2. CG Partners (2011a) Předseda. [on-line], http://www.governance.cz/cs/corporategov ernance/predseda/predseda_s74x8491.htm l Available [11 Feb 2013].
3. CG Partners (2011b) Na co by se mèli členové správních orgánů soustředit $v$ roce 2010? [on-line],

http://www.governance.cz/cs/corporategov ernance/predseda/predseda_s74x8491.htm l Available [11 Feb 2013].

4. Dubovec, J. (2011) Práca s informáciami. [on-line],

http://kst.uniza.sk/predmety/udi/Praca_s_i nformaciami.pdf Available [12 Dec 2011].

5. Jirásek, J.A. (2001) Podnikatelská správa akciových společností (Corporate Governance), Professional Publishing, Prague.

6. Kavalíŕ, P. (2005) Hodnocení corporate governance $v$ České republice. Working Paper CES VŠEM No. 14/2005. ISSN 1801 - 2728.

7. Klírová, J. (2001) Corporate Governance: Správa a ř́zení obchodních společností, Management Press, Prague.

8. Kramoliš, J. and Drábková M.. Product Scale Promoting by Product Placement in the Czech Republic. In: Proceedings of the 18th International Business Information Management Association. International Business Information Management Association. pp 1971-1982.

9. Lacko, B. (2011) Systémový př́stup. [online],

http://lacko.otw.cz/eseje/Systemovy_pristu p.doc.pdf Available [12 Feb 2013].

10. Moiz J., Abidi, M. How is Corporate Governance utilized to meet the Strategic Marketing Goals of an Organization? [on-line], http://saicon2011.ciitlahore.edu.pk/Busines s\%20Ethics/11-1308\%20jami.pdf Available [12 Feb 2013].

11. MPO (2004) Kodex správy a řízení společností založený na Principech OECD (2004) [on-line],

http://download.mpo.cz/get/26403/26370/ 293363/priloha001.pdf Available [14 Feb 2013]. 
12. OECD (2004) OECD Principles of Corporate Governance, OECD Publishing Service, Paris.
13. Porvazník, J. and Ladová, J. (2010) Celostní management. Iris, Bratislava.

14. Slávik, Š. (2009) Strategický manažment. Sprint dva, Bratislava.

Pavel Taraba, Romana Bartošíková and Jana Biliková (2016), Journal of Eastern Europe Research in Business \& Economics, DOI: 10.5171/2016.445900 